\title{
Paideusis
}

\section{Noncognitivism and Autonomy}

\section{Eamonn Callan}

Volume 7, Number 1, 1993

URI: https://id.erudit.org/iderudit/1073285ar

DOI: https://doi.org/10.7202/1073285ar

See table of contents

Publisher(s)

Canadian Philosophy of Education Society

ISSN

0838-4517 (print)

1916-0348 (digital)

Explore this journal

Cite this article

Callan, E. (1993). Noncognitivism and Autonomy. Paideusis, 7(1), 15-29.

https://doi.org/10.7202/1073285ar

(C) Eamonn Callan, 1993

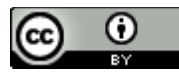

This document is protected by copyright law. Use of the services of Erudit (including reproduction) is subject to its terms and conditions, which can be viewed online.

https://apropos.erudit.org/en/users/policy-on-use/
This article is disseminated and preserved by Érudit.

Érudit is a non-profit inter-university consortium of the Université de Montréal, Université Laval, and the Université du Québec à Montréal. Its mission is to promote and disseminate research.

https://www.erudit.org/en/ 


\section{Noncognitivism and Autonomy}

\section{Eamonn Callan, University of Alberta}

The supposed failure of ethical cognitivism is the beginning of one common argument for the ideal of personal autonomy and its supporting social practices. The argument can be summarized as follows. There is no ethical knowledge that could conceivably be available to us, or at least all current claims to such knowledge are doubtful to a degree that makes them untenable. Therefore, experts to whose authority we should defer regarding ethical decisions simply do not exist. That is tantamount to saying we should act autonomously in making ethical decisions and, if we are to grant the capacity and liberty to make such decisions to others, we need to develop educational and other social practices that nurture the relevant capacity and bestow the necessary liberty.

Another argument for personal autonomy begins by assuming the truth of some variety of ethical cognitivism. People are liable to make mistakes when trying to live good lives, and so they need the psychological and social resources to discover their errors and change their ways when mistakes are made. The necessary resources could not be supplied in a paternalistic and illiberal milieu because good lives need to be lived "from the inside." The piety that might be part of a good life, for example, must be a genuine devotion to a particular creed and not a fearful compliance with priestly authority. Similarly, authentic friendship, or erotic love, or the career that is truly fulfilling and not merely outwardly successful all require that I can affirm and experience these as good from my own first-person, singular perspective. Otherwise, they are not good for me.

This argument falls apart if ethical cognitivism is false. For the possibilities of making mistakes in our attempts to live good lives and then correcting these presuppose that our discriminations about what is good and bad can have some distinctively ethical cognitive content and, if they cannot, the first premise of the argument is false. Similarly, if the claim that good lives must be lived from the inside has no truth value, or a truth value so contestable that the claim cannot be known, it is hard to see how it can be used in defence of autonomy.

The cognitivist and noncognitivist arguments for autonomy might both be fallacious, but they cannot both be sound. I want to show that the noncognitivist argument is fallacious. In so doing, I try to refine and extend a line of thinking I explored, rather too briskly and carelessly, on an earlier occasion. ${ }^{1}$ I shall also try to make the cognitivist argument a bit more appealing than it might seem to people who find it intuitively suspect. The cognitivist case for autonomy is likely to be viewed with suspicion because, even if the noncognitivist defence demonstrably fails, the thought may persist that an argument for autonomy needs noncognitivist premises. For once we say that there is ethical knowledge we can often reasonably claim ourselves or attribute to others, it may seem to follow that we must be ready to recognize marked disparities between one person and another in the possession of that knowledge; therefore, we must accept the institution of ethical expertise and the need for deference to its deliverances; therefore, we must endorse social arrangements that give power to 
those who have the expertise while withholding it from those who have not. In short, ethical cognitivism seems to initiate a train of reasoning that pushes hard against liberal sentiments about autonomy as a social and educational value that has wide, much less universal, application. For those who are averse to this train of reasoning, noncognitivism may seem a necessary bulwark against the dangers of a creeping authoritarianism in our educational and political thought. I hope to show in the last section of this essay that there is no need for the bulwark.

Exponents of the noncognitivist argument need to clear two hurdles. I do not think either hurdle can be cleared. But if they could clear the first hurdle, they would have to collide with the second.

First, they need to show that in saying "Autonomy should be a central value of educational and other social practices," they utter something that is rationally justified, given certain facts about our lack of knowledge in ethical matters. That is to say, they cannot present themselves as just expressing a desire or preference for autonomy and urging others to share it. If that were so, there would be no argument, only exhortation. So their affirmation of the value of autonomy is supposed to be rationally authoritative in this sense: its persuasiveness is thought to be somehow independent of the vagaries of preference, and given that we are rational enough, we are expected to see this and be persuaded, regardless of our pre-reflective preferences regarding autonomy.

We ordinarily think of utterances as having the rational authority I have specified by virtue of reasons for regarding them as true statements. Yet, the grounds which the noncognitivist adduces in support of the claim that autonomy should be a central goal of education cannot be grounds for regarding that claim as true. The grounds that are adduced revolve around the thesis that ethical claims have no truth value, or at least none that we can establish with any tolerable degree of assurance. Since the claim that autonomy should be central to our educational practices is itself an ethical judgment, it cannot be presented in the context of the argument as a statement we have reason to regard as true. Therefore, exponents of the noncognitivist argument owe us an account of how a judgment about something having ethical value can be rationally authoritative without being discemibly true or entailing other ethical claims that are true. ${ }^{2}$ That is the first hurdle.

Here is the second. Whatever criteria are forthcoming for utterances about value that can be rationally authoritative without having a discernible truth value, there will necessarily be possible differences in the competence of human beings to detect when the relevant criteria have been met or not, differences that parallel disparities in our ability to discem whether truth conditions have been satisfied or not. That being so, the noncognitivist is obliged to acknowledge, once the first hurdle has been cleared, that not everyone must be on the same footing when it comes to competence in making ethical judgments. Yet once that acknowledgment is made, any direct inference is blocked from premises about our lack of ethical knowledge to the conclusion that autonomy is ethically desirable for all. Recall that the noncognitivist argument says that because ethical knowledge is unavailable to us so, too, is ethical expertise, and, there- 
fore, we are each of us on an equal epistemological footing in making judgments about good and evil, right and wrong. Autonomy is an ideal that is thrust upon us by virtue of our parity of ethical competence (or noncompetence), or so the argument goes. But we now see that if autonomy is, indeed, a rationally authoritative value in the sense that the noncognitivist argument requires, it cannot be true that there must be the parity of ethical competence (or noncompetence) that the same argument requires. So the noncognitivist argument for autonomy turns out to be incoherent. What is necessary to clear the first hurdle guarantees a collapse at the second.

It will be objected that this ignores the possibility that a defensible noncognitivist conception of when an ethical utterance is rationally authoritative might yield a broadly egalitarian view of ethical competence. If the criteria of rationally authoritative ethical judgment are easily met and entail no standards of excellence above a primitive level of competence, then we could rightly claim that virtually all of us are on the same footing when it comes to making ethical judgments. Such a theory is certainly logically possible, though it is noteworthy that the most carefully elaborated contemporary noncognitivist meta-ethical theory-Richard Hare's universal prescriptivism-certainly does not authorize a demotic view of moral competence. ${ }^{3}$ Moreover, one might also ask why ethical cognitivism cannot yield the desired demotic view. So the crucial issue becomes whether we can justify that view rather than whether noncognitivism of some sort can be vindicated. But if that is the crucial issue, the friends of autonomy would seem to be backed into a corner.

No meta-ethical theory that is not outrageously implausible, whether is is noncognitivist or not, can imply that ethical discrimination is a matter of a near universal competence, like the ability to blow one's nose, which does not allow distinctions between those who are merely good, those who are very good and those who are paragons. Unless we have been completely bewitched by the crudest subjectivism, we know that sound ethical judgment is often immensely difficult. The decision to tell an aged parent about the true nature of her illness, and, if we decide to tell her, the question of how and when to do it; the decision to persist with a troubled marriage, and, if we choose to persist, how to do so without making matters worse-these problems are difficult not only in being emotionally hard on us but also in the deeper sense that they tax our powers of evaluative discrimination. Some people blunder through problems of this sort in a way that shows an appalling myopia or insensitivity; others show a wisdom and greatness of spirit we would hope to emulate in our own crises of the heart. A philosophical conception of art that entailed Michelangelo could draw no better than you or I would be dismissed outright because of that absurd implication, and a meta-ethical conception with an analogous egalitarian implication should be dismissed outright for its analogous absurdity.

So the noncognitivist argument is incoherent as it stands. Once that is granted, any attempt to retreat from the argument while holding onto its premise about the egalitarian distribution of ethical competence flies in the face of the transparently obvious truth that whatever distribution there is must be strikingly inegalitarian. A good argument for valuing autonomy and making it central to our lives and those of our children must be found elsewhere or nowhere. 
The noncognitivist argument as I have presented it so far is a philosophical orphan. I have attributed it to no particular philosopher. My argument might reasonably be greeted with some scepticism on that count. It is notorious that philosophical orphans are easier to push around than the muscular progeny of particular, intellectually-formidable practitioners. Does the noncognitivist argument look any better when we examine how it might be developed by a philosophically astute advocate? I do not think it does, but the question is worth pursuing. I shall assign the leading role in the defence of the argument to John White, with Bernard Williams making up a one-man supporting cast.

In The Aims of Education Restated, White argues that to encourage children to develop into autonomous adults there is no body of expertise which can allow one person to say of another: "Given that he wants to do both $A$ and $B$, and the consequences of doing $A$ are such and such and the consequences of doing $B$ are such and such, then he ought, on balance, to do $B$, not $A$. There are no ethical experts when it comes to making judgments of this sort." The fact that no one has grounds for making this sort of judgment means that we could never have reason to rear children to believe that "blind reliance" on authority is the right way to resolve conflicts of desire or moral dilemmas. That leaves us with but one alternative, which is to teach them to confront conflicts and dilemmas autonomously, using the advice of others perhaps, but never uncritically following their direction. ${ }^{4}$ Notice that the desirability of autonomy is supposed to be established here simply by means of the withering effect of the absence of ethical expertise on the grounds for all rival ideals. Autonomy is the only thing left standing as a criterion for determining our own good, and the good of our children, after noncognitivism has taken its lethal toll on everything else. ${ }^{5}$

There is nothing here to indicate that the first hurdle can be cleared. But for the sake of argument, assume that some credible noncognitivist account is available of when an ethical judgment could count as rationally authoritative, so that it is at least conceivable that "We should encourage our children to be autonomous" might be such a judgment. The obvious question to ask now is why autonomy should not succumb to the same noncognitivist critique that lays waste to alternative ideals. Suppose that there is no body of ethical expertise. It follows that no one can make a judgment about the good of someone else that is warranted by such expertise (for example, he ought, on balance, to do $B$, not $A$ ). Any such judgment would be arbitrary, given that a body of ethical expertise would have to be available to make it otherwise, and, therefore, encouraging children to rely on the authority of others would be equally arbitrary.

Unfortunately, the supposition that there is no ethical expertise has precisely parallel implications about the autonomous judgments that children might learn to make about their own good. If there is no body of expertise, I cannot make a judgment about my own good that is warranted by such expertise (for example, I ought, on balance, to do B, not A). Any such judgment would be arbitrary, given that a body of expertise would have to be available to make it otherwise, and, therefore, encouraging children to leam to make their own ethical judgments would be equally arbitrary. If noncognitivism rules out any epistemologically privileged perspective on the good of others, it must, by the same token, rule out any epistemologically privileged perspective on one's own 
good. White sees the former implication of noncognitivism but not the latter, but it is only by overlooking the latter that he can say he say noncognitivism supports autonomy as an educational ideal. So the argument collapses even before the second hurdle is reached.

But that is not the whole story. In White's recent Education and the Good Life, a noncognitivist argument for autonomy is presented that is strikingly different from its predecessor. ${ }^{6}$ The difference needs to be understood in the wider context of recent developments in moral philosophy. The varieties of ethical noncognitivism that held sway in Anglo-American philosophy for most of this century have claimed universal application. Our inability to assert ethical propositions that have a discernible truth value was supposed to be a necessary limit on human knowledge, even though recognition of that inability was more or less exclusively confined to a few clever people in philosophy departments in very recent history, along with whomever they could persuade to share their eccentric views. But the last decade has brought to prominence a different and perhaps more interesting species of noncognitivism. The ruling idea of what might be termed historicist noncognitivism is that under certain cultural conditions ethical knowledge can be and has been possessed by human beings, though the circumstances of modernity have deeply eroded or destroyed these conditions. Our social predicament is either one that requires us to recreate the cultural conditions that made ethical knowledge possible (the Alasdair MacIntyre option), or else we must find ways to establish terms of social co-operation and ways to infuse our individual lives with point and purpose without the direction that ethical knowledge can furnish (roughly ${ }^{7}$ the Bernard Williams option). To be sure, one may think, as Williams evidently does, that talk of options in this connection is naive. That is presumably the point of his famous one-liner about there being no route back from reflectiveness. ${ }^{8}$ The reflectiveness at issue here is that of the autonomous agent who must confront questions of right and wrong, good and evil, without the kind of knowledge that conditioned practical judgment under more propitious, or at least simpler, cultural circumstances.

The discussion of autonomy in White's Education and The Good Life strongly echoes Williams' Ethics and the Limits of Philosophy. White explicitly grants that good lives might be led without autonomy under some historical conditions. But ours is an autonomy-supporting society in that powerful and virtually ineradicable features of our institutions militate against good lives that forgo the ideal of autonomy. ${ }^{9}$ So here again autonomy supposedly succeeds against rival educational values through a kind of attrition. The difference is that here the attrition is wrought not by the universal absence of ethical expertise, but by the momentum of social tendencies that deny us any avenue away from autonomy/reflectiveness.

Our educational and political possibilities are at least conceivably constrained in this way by irreversible social tendencies. Therefore, the latest version of the noncognitivist argument cannot be defeated merely by reiterating the considerations that sufficed to undermine the universalist version. For example, the historicist argument seems to circumvent what I called the first hurdle. If autonomy is a value we are simply landed with as a matter of our sociological fate, so to speak, then the question of what account we can give of its value that is consistent with our lack of ethical knowledge ceases to have any 
practical import because, regardless of how we answer the question, we are still going to be landed with autonomy.

I want to pursue two independent lines of criticism against the noncognitivist argument at this point. First, the claim that the options modernity affords are constrained in a way that must favour autonomy is much more extravagant and implausible than it might initially seem. I shall concentrate mainly on Williams' defence of the claim because his argument is explicitly invoked and commended at the culmination of White's attempted justification of autonomy, ${ }^{10}$ and White's account of this particular matter does not improve on Williams' efforts. Second, I shall argue that whatever conception of personal autonomy noncognitivism could support would be a thin and unattractive ideal.

The pivotal claim in the historicist argument is that no ethical option is left open to us under current social conditions other than a conception of autonomous agency that requires us to get along, somehow, without ethical knowledge. How are we to construe the claim that there is "no option" save this one possibility? Perhaps the most obvious interpretation would be that empirical contingencies are such that, like it or not, nothing else is even eligible as a way of life. The choices people are, in fact, going to make in modern (or postmodern) societies, and the ways in which political, economic, and other institutions are going to develop, will all conspire to make lives grounded in anything other than noncognitivist autonomy virtually unliveable, despite all attempts we might make collectively and individually to pull in other directions. But once this empirical reading of the "no-option" thesis is made explicit, its reckless speculativeness is also apparent.

It is certainly foolish to deny that modernity has spawned social pressures that have to a degree undermined ethical knowledge (or what was taken to be knowledge) in premodern societies. Yet, it is equally foolish to deny the pervasive force of countervailing social pressures, pressures we could well choose to reinforce by educational and other means. To dismiss the contemporary resurgence of Islamic (and Christian?) fundamentalism, as Williams does, as the despair of those who are on history's losing side looks more like wishful thinking than dispassionate social analysis. ${ }^{11}$ (It is also depressingly reminiscent of the fundamentalists' patronizing charge that we secularists know, deep down, that our social hopes are futile.) Furthermore, even if unreflective traditionalism will, as a matter of empirical fact, be steadily marginalized in the future, it would not mean that a noncognitivist autonomy must gradually become the only option left open to us. There is also the the possibility of an unreflective, anti-traditional consumerism. Only by ignoring the enduring potency of traditional ethical patterns in modern societies, and then eliding the distinction between autonomy and other viable ways of life that are hostile to those patterns, can one give some semblance of plausibility to the "no-option" thesis on an empirical reading.

The bewildering internal complexity of contemporary societies also warrant misgivings about White's suggestion that an education for autonomy in some strong sense could be justified as a reliable means to happiness. ${ }^{12}$ The fact that our children grow up in societies containing some practices that conduce to autonomy alongside others that move in opposing directions, and the fact that institutions impinging heavily on their lives, such as the school and the mass media, may themselves harbour discrepant attitudes regarding the value of 
autonomy, all make it very unclear whether a truly self-directed life, rather than one aligned with other extant cultural patterns, is the high road to personal felicity. After all, it is simply false that lives of unreflective consumption or lives that sustain a dogmatic allegiance to some ethical tradition can no longer be happily led in our midst.

But the empirical reading is not the only interpretation of the "no options" thesis. At one point, Williams suggests that trying to recover traditional ethical knowledge by suppressing reflection "can lead to nothing but disaster, rather as someone who finds that having children has disrupted her life cannot regain her earlier state by killing them."13 So there might be a route back from reflectiveness, but whatever it is, it will be like murdering your own flesh and blood. Therefore, the "no-option" thesis is not straightforwardly empirical; the thesis is really about the absence of alternatives that are not morally terrible. Call this the moralized reading of the thesis. It is hard to know exactly what to make of this in the absence of a detailed accounting of these empirically feasible but morally terrible options, and Williams supplies no such thing, but there is reason to suppose that this is an unpromising line of thought.

The moral horrors that attend the available alternatives to autonomy must be conceptually independent of the constellation of values that surround that ideal if the defence of the "no-options" thesis is not to become viciously circular. One might say, for example, that large-scale censorship and massive indoctrination in schools would be needed to turn back the reflective tide, and these are evils too dire even to contemplate. That suggestion will strike a responsive chord among those who deeply identify with liberal values, and in a hyperbolic moment, we might even compare such measures to killing our own children. After all, we would be witnessing the destruction of values that are part of our moral identity. But the rhetorical appeal of that argument for some of us must not disguise its vicious circularity. If one says there is no morally acceptable choice because any other option would destroy autonomy along with its associated values, like free speech or an education that eschews indoctrination, then one simply begs the question in favour of autonomy because no reason is given to those who do not already embrace the ideal to regard the alternatives as morally unacceptable.

The "no-options" thesis on the moralized reading can only break outside a vicious circularity by appealing to values like the avoidance of cruelty, suffering, and the like, which have application beyond the conceptual orbit of autonomy. So thoughts of the Inquisition or at least smaller-scale horrors may occur to us as we try to imagine the alternatives. But the reasons for regarding the "no-options" thesis as unreasonable on the empirical interpretation also suffice to expose the implausibility of the moralized reading at this point. It would be right to think that terrible things must be done to diminish the cultural salience of autonomy if the impetus of history were massively on its side. But once we acknowledge the pressures of opposing currents in contemporary cultures, the feasibility of supporting these in undraconian ways has to be conceded. Educational policies that strongly favour traditional modes of moral understanding will be an obvious option, and, if we oppose such policies, it is precisely because we see them as a real threat to liberal values whose durability across generations is by no means assured. Similarly, if the influence of unreflective consumerism is to win against the values of autonomy, we do not have 
to imagine a moral price being extorted that would dismay those who are not already friends of autonomy. Closing down philosophy departments while opening up schools of hotel management and catering is the sort of thing that will nudge the process along very nicely, ${ }^{14}$ and whatever suffering might be involved can be mitigated by generous severance packages.

The second line of criticism I want to press against the historicist argument has to do with the content of the ideal of autonomy it could give us if the "no-option" thesis were defensible (which it is not ). This line of criticism might also be pursued against noncognitivist arguments for autonomy that aspire to universal relevance. However, I wanted to defer consideration of the nature of autonomy as an ideal until this point in order to show how the argument in both its universalist and historicist versions can be shown to unravel even before we confront difficult questions about just how the ideal is to be understood.

The ideal the noncognitivist argument supports must be of an agent who self-consciously lives without anything in the way of ethical knowledge. The requirement of self-consciousness is important to stress. If putatively autonomous agents were unaware that they lack and cannot get ethical knowledge, then their autonomy would be marred to the extent that their choices and responses are conditioned by what they wrongly take to be such knowledge or the real possibility of acquiring it. This raises challenging questions about the phenomenology of the good life when construed in noncognitivist terms. What would it be like really to live noncognitivist autonomy in this self-conscious way? Could we live like this without slipping into the pretence that we have ethical knowledge? If we could pull it off, would this really be a way we want to live? I shall argue that the answers to these questions are unlikely to be favourable to the noncognitivist ideal.

One of the more intriguing (and alarming) theses of Ethics and the Limits of Philosophy is that reflection tends to destroy ethical knowledge. ${ }^{15}$ It would carry us too far afield to assess that thesis, and it is unnecessary to what I want to argue anyhow. What is undeniable, however, is that reflection often dissolves assured ethical convictions-whether they count as ethical knowledge is another and, for my purposes, irrelevant matter-without installing new assured ethical conviction on the subject of reflection. The early Platonic dialogues give masterly examples of the skill of Socrates in eliciting this kind of reflection. Yet, the befuddled state of his interlocutors who come to recognize their own ethical ignorance toward the end of the dialogues evokes pity as much as anything else. If autonomy without ethical knowledge is a state of permanent befuddlement, it is nothing to write home about. Williams is aware of this difficulty, and he sketches an ideal of agency that entails an "ethical confidence" to militate against paralysing indecision. The confidence that is desirable is not rooted in the illusion that we can regain the knowledge that is irrevocably lost, but that is not to say it is an attitude that can do without cognitive sustenance. On the contrary, Williams notes that "in the process of losing ethical knowledge, we can gain knowledge of other kinds, about human nature, history, what the world is actually like. We may gain knowledge about, or around, the ethical. Inside the ethical, by the same process, we may gain understanding." 16 What leaves me deeply puzzled here is how an ethical understanding that is not ethical knowledge, working in alliance with knowledge about, or around, the ethical, can nourish a confidence about how one should 
live that will effectively restrain bewilderment and indecision. This looks like a psychological thesis that cannot be demolished (or vindicated) on conceptual grounds, and I think Williams would agree, but further scrutiny of the relevant concepts shows how thin the ice is that he is skating on.

Suppose Jones believed at a certain point in her life that homosexual acts were a moral abomination. Indeed, Jones thought she knew this, and in support of her claim to knowledge cited reasons pertaining to the value of sexual purity, and so on. Because she thought she knew this, Jones confidently opposed legislation intended to secure the civil rights of gays and lesbians, and acted decisively in many other ways that her supposed knowledge seemed to warrant. But Jones is drawn by a friend into a reflective process in which she is disabused of her homophobic convictions. Whether this is best described as reflection destroying knowledge or destroying beliefs masquerading as knowledge does not matter at all for my present purpose. In either case, Jones is now aware that she can no longer claim as items of ethical knowledge what she once claimed as such. Obviously, the reflection she engages in might bear abundant cognitive fruit about, or around, the ethical. Her knowledge of human nature and history are deepened, perhaps, as she becomes familiar with literature in the social sciences about homosexuality. Inside the ethical, by the same process, she gains understanding of the views of gays and lesbians who are demanding respect for their rights, and understanding also of the errors that once underpinned her beliefs about them.

Yet, if we are to understand the case in terms of Williams' conception of ethical agency, the reflective process cannot yield particular kinds of cognitive fruit we might expect and hope for. ${ }^{17}$ The process cannot lead Jones to say "I know that homosexuals should be treated with the decency and dignity we accord to others." On Williams' conception, Jones can no more know this than she can know that homosexuals are perverts who exist beyond the moral pale, and given the requirement of self-consciousness, Jones must be acutely aware that she can know neither of these things. It is easy to see how the reflective process, conceived in Williams' terms, could dispel the ethical confidence that was once sustained by what Jones took to be knowledge. What is hard to see is how the knowledge and understanding the same process supplies, in place of what it destroys, could arouse an alternative confidence about how to respond ethically to human beings who are homosexual. I can see nothing in the knowledge and understanding she gains through reflection to deter Jones from saying this: "Since I have no ethical knowledge about how homosexuals should be treated, perbaps I might as well persist in my old ways or maintain a steady neutrality when questions about the oppression of gays and lesbians arise." Even if Jones does not remain mired in indecision but musters the will to proceed decisively in some direction, in so doing she would look to me like a rather jaunty nihilist instead of someone exhibiting an ethical confidence I might aspire to for myself and my children.

The conception of autonomy that emerges in Education and the Good Life is more substantial and attractive than Williams' vaporous ideal of reflective confidence, but what makes White's conception more attractive, for me at least, is precisely the cognitivist undercurrents it contains. Consider his very vivid example of a someone who lacks what he calls autonomy in the "strong" sense: 
I heard the other day of a young woman who works as a home help in the day and as a security officer at night, snatching a little sleep in the afternoons. She is saving up for her wedding in December. Her dress will cost her 1000 pounds and she is inviting 700 guests. At the same time, she has cut herself off from all interest in the outside world beyond her immediate family and friends. She has no idea what is going on in the wider world and does not care. As she says, she lives only for herself and sees nothing wrong about this. 18

Suppose that this is the best that can be said about the young woman's life: there are no hidden depths that White's description fails to capture. I suspect that this is just the sort of situation in which serious people without a philosophical axe to grind would say things like 'Here is someone who does not really 'own' her life, who bas not learnt to exercise the self-direction worth having," and the like. In other words, cases like these are just where the language of autonomy seems to have its natural home in non-philosophical talk about how we should and should not live. But how are ascriptions of autonomy and its opposing vices warranted there? I would say that the young woman is not autonomous because she evidently has not thought with any success at all about the difference between what is important and what is not. She is absorbed by what is trivial and virtually oblivious to what is worthwhile. If she had thought with some success about what matters in human life, she would not be enthralled by a popular culture that exalts conspicuous consumption and self-display. Then her will and identity would be her own rather than the property of that shabby culture, and she would be alive to the wide world of value that exist beyond the circle of her currently petty concerns.

Perhaps White would recoil from this interpretation of the example. The discussion that follows it in his book does not rule out the possibility that he would. Maybe what I have called "cognitivist undercurrents" in his conception of autonomy are really my own cognitivist projections. What is very clear, however, is that the White who wrote The Aims of Education Restated and Towards a Compulsory Curriculum would have to recoil. He would have to do so because the interpretation I have given of his example is expressed in the language of an unabashed ethical cognitivism. Autonomous agents are differentiated from others in part, at least, by ethical knowledge-knowledge of the difference between the important and the petty, for example-and they live in accord with that knowledge. To be sure, noncognitivists will be tempted at this point to wheel out the familiar artillery of philosophical arguments against cognitivism. 19 But before the reader starts firing away, White's example might usefully be probed a bit further.

Suppose we say that the problem with the woman in the case I have described is not that she does not think successfully about the difference between what is important and what is not, but simply that she does not think enough. If she had received an education that enabled her to understand something like the full range of possible objects of desire in our society, and then chose the life she wanted, that would suffice to make her autonomous in the strong sense. One apparent advantage of this conception of an education for autonomy is that it does not require us to invoke any allegedly knowable distinctions between the important and the trivial, and so on. But suppose a young woman who has been the recipient of this education now decides to spend 2000 
pounds on that wedding dress, double her guest list, and narrow the sphere of her interests even more. Are we really obliged to say admiringly "Now there's autonomy!'?

The feeling that we are obliged to say this is natural if we are convinced that noncognitivism is true and that its truth entails the desirability of an autonomy that is attainable without the resource of ethical knowledge. I have tried to show that the available noncognitivist arguments do not support the desirability of any such thing. Of course, to show that noncognitivism supports no such thing is not to refute noncognitivism. So the question of what kind of education befits noncognitivism remains interestingly open. One might reasonably opt, for example, for a moral consensus and an ethical confidence that is produced through some combination of conditioning and indoctrination, and I am inclined to think that some option of that kind is the only sensible noncognitivist route around the impasse that Williams' argument creates. Therefore, even if one is convinced that the cognitivist ideal I have pointed to will inevitably founder because of its meta-ethical liabilities, one still has no reason whatever to embrace a noncognitivist version of the ideal.

\section{III}

The argument I have presented in this essay is sure to leave those who are drawn to the value of autonomy and yet philosophically sympathetic to noncognitivism with at least one nagging doubt. Maybe noncognitivist premises, whether of the universalist or historicist variety, are not enough to justify autonomy. Perhaps, also, we still lack a sufficiently rich and precise characterization of what it is like to live self-consciously without ethical knowledge or the aspiration to achieve it, a characterization we could honestly commend as depicting a good way to live for ourselves and our children. But the project of defending autonomy on cognitivist grounds and conceiving it in a way that includes ethical knowledge may still seem deeply paradoxical. In positing ethical knowledge, which some have and others lack, are we not on the slippery slope to social provisions that would favour people whose claim to knowledge we are prepared to recognize, while discriminating against others, like the lightminded woman in White's example, whom we contemptuously dismiss as ethically ignorant? The record of at least some philosophers who have been ethical cognitivists-Plato, Aristotle, and even Kant ${ }^{20}$ come to mind-suggests that this particular slippery slope may be hard to resist. The noncognitivist friends of autonomy are at least owed some account of how its cognitivist friends are going to avoid slipping.

There is a quick response to this which is adequate so far as it goes, but does not really touch the heart of the matter. If there is a slippery slope problem here, it is not created by cognitivism per se; it is, instead, a consequence of the fact-which cognitivists and noncognitivists alike must reckon with-that competence in making ethical judgments is unevenly distributed among human beings. Being able to make ethical judgments is not like being able to blow your nose; it is like being able to sing, paint in oils, or solve mathematical equations. Some of us do much better than others, and some of us are truly awful. Furthermore, the slippery slope is resisted so long as we distinguish between autonomy as a personal and educational ideal and the zone of personal sovereignty to 
which each citizen of a liberal society is entitled-a zone that gives one the right to make many decisions that others could rightly regard as revealing a conspicuous lack of autonomy. So, in saying that White's light-minded woman lacks autonomy, I am not implying that wise people are entitled to come along and force her to buy a cheaper wedding dress, invite fewer people to ber wedding, and expand the horizons of her juvenile interests. That is not implied because people who lack autonomy do not thereby forfeit the right to personal sovereignty.

This does not go to the heart of the matter because serious concern about the slippery slope arises precisely from the suspicion that cognitivism cannot support any robust conception of personal sovereignty. Suppose you see someone acting in a way that appears very rash to you. You feel that this behaviour is likely to cause some significant harm to the individuals, and you have the power to stop it. However, you are a noncognitivist, and so the desire to interfere might be checked by the following thought: "I do not, indeed I cannot, know what is good for this person, and so I cannot know that my intervention will do any good." But if you are an ethical cognitivist, your inclination to intervene cannot be checked by that thought. As a cognitivist, you believe that knowledge of what is right and good is available, and you may be cock-sure that you have it at this very moment. So noncognitivism supports a humble acceptance of our incapacity to make judgments about the good of others, and this puts a brake on the development of patemalistic proclivities, whereas cognitivism lends itself to an arrogant hubris regarding interference in others' lives. Cognitivist arrogance is what drags us down the slippery slope.

If this is the heart of the matter, then I think noncognitivist anxieties about the slippery slope can be easily dispelled. These anxieties depend on an unreasonably narrow view of the attitudes toward the good of others that cognitivism might encourage. This becomes obvious if we go back to the thumbnail sketch of a cognitivist argument for autonomy that I gave at the beginning of this essay. I said that one premise of the argument is that good lives must be lived from the "inside." The goods that confer meaning upon my life must be such that I can truly experience their goodness from my own standpoint. This immediately suggests reasons why we might hesitate to make glib judgments about the good of others, and why we might be reluctant to interfere even when we rightly feel confident in making such judgments. The importance of the inside perspective upon the good means that a particular life that seems strange, even repellent to me, might contain sources of value to which I am blind by virtue of the idiosyncrasies of my temperament and the limits of my imagination. This possibility typically restrains me from being cock-sure about goodness or badness in other people's lives. I know that my distinctive sensibility must not be confused with universal human nature and that my capacity to imagine lives very different from my own is often pitifully weak.

Nevertheless, there are occasions when I might feel entitled to claim knowledge-not certainty, of course-that another life is bad or not good enough. (If you think I have been too hard on the light-minded woman in White's example, you can dwell on a useless life of your own devising at this point-perhaps a reclusive misanthrope who devotes his life to watching soap operas on television or a doctrinaire behaviourist in a faculty of education.) The ethical judgments I make on such occasions typically do not give me anything 
like sufficient grounds to impose my judgment upon the other person. For even when we think we know, and really do know, that a particular life is pretty bad, the importance of the inside view of the good is such that external interference is rarely a sensible way to try to bring about improvement. Forcing the woman in White's example to spend her money on what is worthwhile, dragging her off to the opera and museums, requiring her to take courses on philosophy, and so on, would all be stupid things to do if we really want to make her life better because these things are not good for her unless she can experience their goodness from the inside, and coercion is a rather unpromising way of trying to elicit the necessary experience, to put it mildly.

The cognitivist argument I have just outlined for the importance of personal sovereignty cannot support a blanket prohibition on paternalism, but for reasons I have rehearsed elsewhere, I do not think such a prohibition is desirable. ${ }^{21}$ In any event, so long as we heed the implications of this argument, there can be no inexorable slide down the slippery slope. A judicious humility about our ability to see what is good for others and a recognition of our almost negligible capacity to advance that good through coercion are not the same as the indiscriminate scepticism concerning ethical judgments that noncognitivism would support, but I would also claim that they provide grounds for the value of personal sovereignty that are as strong as we could reasonably want.

I have tried to show in this final section of the essay that noncognitivism is not needed to arrest any drift toward authoritarianism. A cognitivist conception of personal autonomy as a demanding ideal of ethical discrimination, an ideal that is instantiated to markedly varying degrees across different lives, readily coheres with a robust conception of personal sovereignty that can shield one against external interference even when one is not notably autonomous. This is certainly not enough to vindicate the project of constructing an account of personal autonomy as an educational ideal in cognitivist terms. But I think it should be clear at this stage that for the friends of autonomy, the cognitivist project is the only game in town. ${ }^{22}$

\section{Notes}

${ }^{1}$ Eamonn Callan, Autonomy and Schooling (Montreal and Kingston: McGill-Queen's University Press, 1992), 41-42.

${ }^{2}$ Showing how such entailments are to be avoided is perhaps the major problem posed by the first hurdle. Suppose the noncognitivist comes up with an argument for the wrongness of slavery. It must be shown that this does not entail "It is true that slavery is wrong," or "It is false that slavery is not wrong." If these entailments hold, then ethical cognitivism is true.

${ }^{3}$ Hare's prescriptivism is the meta-ethical foundation for a "two-level" version of utilitarianism. The critical level of moral thinking represents an ideal of ethical competence so taxing that Hare figuratively represents its ideal practitioner as an archangel. For example, see R.M. Hare, Moral Thinking (Oxford: Clarendon Press, 1981), 46-47.

${ }^{4} \mathrm{~J}$ ohn White, The Aims of Education Restated (London: Routledge, 1982), 51.

${ }^{5}$ There is a cognitivist thesis that is easily confused with White's position 
here. It might be said that each individual is always in the best position to know her own good, and, therefore, ethical expertise concerning the good of others is always a hoax. This is much too crude as it stands, though in the final section of the paper, I shall argue in defence of a cognitivist thesis akin to this one.

John White, Education and the Good Life (London: Cogan Page, 1990), 95-105.

'I say "roughly" because Williams' does allow for the possibility that some of the ethical knowledge that is only possible through so-called "thick" concepts can survive the reflective criticism that modern social conditions provoke, and he even suggests that we shall fare better ethically so far as such concepts can survive. But Williams is frankly pessimistic about the possibility of much of this knowledge surviving, and, hence, there is the need to find alternative sources of ethical motivation and direction in our lives. See his Ethics and the Limits of Philosophy (Cambridge, MA: Harvard University Press, 1986), 148, 200.

8 Ibid, 168.

${ }^{9} \mathrm{John}$ White, Education and the Good Life, 99-103.

10 Ibid., 103.

${ }^{11}$ Bernard Williams, Ethics and the Limits of Philosophy, 165.

12 John White, Education and the Good Life, 96.

${ }^{13}$ Ibid., 168.

${ }^{14}$ This was the fate of the philosophy department at the University of Surrey in the early 1980 s.

${ }^{15}$ Bernard Williams, Ethics and the Limits of Philosophy, 148. For a penetrating critique of Williams' argument on just this point, see Jane Heal, "Ethics and the Absolute Conception," Philosophy, 64, 1989, 61-65.

${ }^{16}$ Ibid., 168.

${ }^{17}$ Strictly speaking, "cannot" is too strong a word here since Williams does allow for the possibility that some of the ethical knowledge encapsulated in thick ethical concepts might survive reflective challenge (see note 9 above). Therefore, if decency and dignity turned out to be thick concepts that withstand reflection, they might authorize a claim to ethical knowledge about the way homosexuals should be treated. But so far as Williams allows for this possibility, his argument contains traces of a faint and residual ethical cognitivism. I have no quarrel with this, except that I would prefer a cognitivism that was neither faint, nor residual. My quarrel is with the Williams who thinks that reflection can provide knowledge and understanding of a kind that is a substitute for ethical knowledge in the grounding of ethical confidence, and so this is the Williams upon whom I concentrate.

${ }^{18} \mathrm{John}$ White, Education and the Good Life, 100.

${ }^{19}$ It should be stressed, however, given the state of the art in meta-ethics, that it is far from obvious that the noncognitivists have the best arguments. The last couple of decades has witnessed a remarkable florescence in AngloAmerican meta-ethics with a variety of cognitivist theories emerging to prominence. For a magisterial survey of the current field, see Stephen Darwall, Allan Gibbard, and Peter Railton, "Toward Fin de Siecle Ethics: Some Trends," The Philosophical Review, 101(1), 1992, 115-189.

${ }^{20}$ The case of Kant is perhaps especially disturbing because he is the cognitivist exponent of personal autonomy par excellence. For a penetrating 
discussion of the paternalistic currents in Kant's moral philosophy, see Joel Feinberg, Harm to Self (New York: Oxford University Press), 1986, 94-96.

21 See Eamonn Callan, Autonomy and Schooling, 100-122.

${ }^{22}$ William Hare and an anonymous reviewer gave very helpful editorial advice on an earlier draft. I am also grateful to John White for stimulating correspondence and conversation about questions discussed in this essay. 